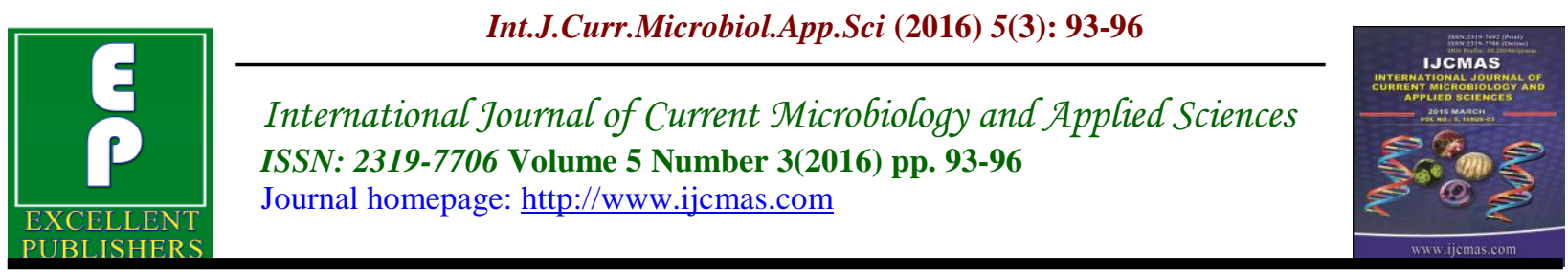

Original Research Article

http://dx.doi.org/10.20546/ijcmas.2016.503.013

\title{
The Parasitic Fauna of the Exotic Fish Tilapia zillii in the Middle and South of Iraq
}

\author{
Mohammad K. Mohammad* \\ Iraq Natural History Museum, University of Baghdad, Baghdad, Iraq \\ *Corresponding author
}

\begin{abstract}
A B S T R A C T
Keywords

Tilapia zilli,

Parasitic fauna, Contracaecum sp., Iraq.

\begin{tabular}{l}
\hline Article Info \\
\hline Accepted: \\
12 February 2016 \\
Available Online: \\
10, March 2016
\end{tabular}

A collection of Redbelly Tilapia Tilapia zillii collected from the middle and south regions of Iraq was examined for their parasites. A larval form of Contracaecum sp. with infection rate of $0.07 \%$ and protozoa cysts with infection rate of $1.4 \%$ were recovered from the visceral cavity and intestine of the fish respectively. The results were discussed with pertinent literature. The cysts could not be identified and more future work is needed to clarify their situation. Neither blood parasites nor ectoparasites were detected in this collection.
\end{abstract}

\section{Introduction}

The Redbelly Tilapia Tilapia zillii (Gervais, 1848) (Osteichthyes, Perciformes, Cichlidae) is native to Africa and Eurasia in tropical range (Teugels and Thys van den Audenaerde, 1991), and considered now one of the most widely distributed exotic fish in the world, second only to common carp (Abidemi-Iromini and Eze, 2011). It inhabits freshwater, brackish, and benthopelagic water with pH range 6-9 (Riede 2004), and prefers shallow and vegetated areas (Eccles, 1992). It is used in aquaculture, mosquito control, and weed control. It has established outside its native range in more than 90 countries (Abidemi-Iromini and Eze, 2011).

This fish species was first recorded in Iraq by Saleh (2007) at Mussayab, on Euphrates River, and then it was recorded for the first time in Al-Dalmaj Marsh which is situated between Wasit and Al-Diwaniya Provinces in the middle of Iraq by Al-Zaidy (2013). By now it is believed that this species is wide spread throughout Iraq. It is believed that introduction of this fish to Iraqi inland freshwater was with serious consequences on the existence of the endemic local fish fauna and could result in remarkable decline to the native fish populations. This fish is considered now a serious invasive species in Iraq.

On the other hand, the health of fish is affected by parasites which make them susceptible to secondary infection by disease causing agents (Al-Maliki et al., 2015), also the parasites disease of fish reduces the amount of food available to people around 
the globe (Bichi and Ibrahim, 2009). The parasites usually affect the marketability of commercially produced fish, thus raising a lot of public health concerns (Barson, 2004).

Al-Sa'adi et al. (2012) were the first to report on the parasites of this exotic fish in Iraq depending on a collection captured at the Euphrates River at Al-Musaib city, Babylon province recording 17 species of parasites. Then (Al-Maliki et al. (2015) studied the incidence of parasites in this species collected at Tigris at north of Qurna in the south of Iraq reporting 4 species of parasites.

The aim of the present study is to determine the identity of parasitic fauna in the exotic fish $T$. zillii collected in the middle and south of Iraq.

\section{Materials and Methods}

The total number of fishes used in this study was 148 specimens with lengths ranged 9$23 \mathrm{~cm}$. They were collected mainly from AlDalmaj Marsh, Al-Diwaniya Province (60 fishes in the middle) and Central Marshes, Thi Qar Province (88 fishes in the south). Fish specimens were purchased alive from fishermen directly at the time of removing their nets from water. The samples were put in cool box with some ice pieces and transferred as soon as possible to the lab. The mouth cavity of each fish was opened and searched for leeches that might be attached to its surface. Blood smears were taken through puncturing the heart area on the ventral side of the fish, air dried, fixed with absolute ethanol or methanol and stained with Giemsa's stain at strength 1:10 at $\mathrm{pH} 7.2$ for one hour. The skin of the fish was examined using a suitable hand lens and smears prepared by scrapping the skin, gills removed from the body and carefully searched, and the intestine were cut and opened to search for parasites.

\section{Results and Discussion}

Examination of fish specimen of the present collection revealed presence of two types of parasites; all infections were from Central Marshes in the south (Table 1). In one occasion, a larval stage nematode of a species of genus Contracaecum Raillet and Henry, 1912 (Nematoda, Ascaridoidea, Anisakidae) was observed, this constitutes $0.07 \%$ of the total infection and $1.1 \%$ from the collection of the southern region while the second parasite was unidentified protozoa cysts appeared in two fishes which counts to $1.4 \%$ of the total infection and $2.3 \%$ of the southern area. The total infection rate for both species of parasites in the southern region was $3.4 \%$.

The very low rate of infection and its absence in the middle region agrees with Mhaisen et al. (2015) who found no monogenean parasites in $T$. zillii specimens captured in the Euphrates River at AlMusaib City, Middle of Iraq. Although of the general smaller sample size from both sites of collection, the absence of parasites in fishes of middle region may reflect some difference in the vector potentiality of both regions.

However, water temperature, season and region affect the incidence and abundance of a parasite in the host. Infection with Contracaecum sp. was found in the pericardial cavity while the protozoa cysts were in the intestine. Parasite locations of both cases of infection agree with Aloo (2002) and Al-Sa'adi et al. (2012) who found Contracaecum sp. in the pericardial cavity and with Bichi and Ibrahim (2009) who found the protozoa cysts in the intestine.

The nematode Contracaecum is an anisakid nematode that infects fish-eating birds and marine mammals (Barson, 2004). Larval 
stages of Contracaecum occur in the body cavity and mesenteries of fish while the adults occur in the gut of piscivorous birds, notably pelicans, cormorants, herons and darters (Barson, 2004; Whitfield and Heeg, 1977).

Table.1 Parasite Species, No. Examined, No. Infected, and \% Infected in Middle Region, South Region, and Total Studied Area in Iraq

\begin{tabular}{|l|c|c|c|c|c|c|c|c|c|}
\hline \multirow{2}{*}{$\begin{array}{c}\text { Parasite } \\
\text { species }\end{array}$} & \multicolumn{3}{|c|}{ Middle region } & \multicolumn{3}{c|}{ South region } & \multicolumn{3}{c|}{ Total area } \\
\cline { 2 - 10 } & $\begin{array}{c}\text { No. } \\
\text { exam. }\end{array}$ & $\begin{array}{c}\text { No } \\
\text { inf. }\end{array}$ & $\begin{array}{c}\% \\
\text { inf. }\end{array}$ & $\begin{array}{c}\text { No. } \\
\text { exam. }\end{array}$ & $\begin{array}{c}\text { No. } \\
\text { inf. }\end{array}$ & $\begin{array}{c}\% \\
\text { inf. }\end{array}$ & $\begin{array}{c}\text { No. } \\
\text { exam. }\end{array}$ & $\begin{array}{c}\text { No. } \\
\text { inf. }\end{array}$ & $\begin{array}{c}\% \\
\text { inf. }\end{array}$ \\
\hline $\begin{array}{l}\text { Contracaecum } \\
\text { sp. }\end{array}$ & 60 & - & - & 88 & 1 & 1.1 & 148 & 1 & 0.07 \\
\hline Protozoa cyst & 60 & - & - & 88 & 2 & 2.3 & 148 & 2 & 1.4 \\
\hline total & - & - & - & 88 & 3 & 3.4 & 148 & 3 & 2 \\
\hline
\end{tabular}

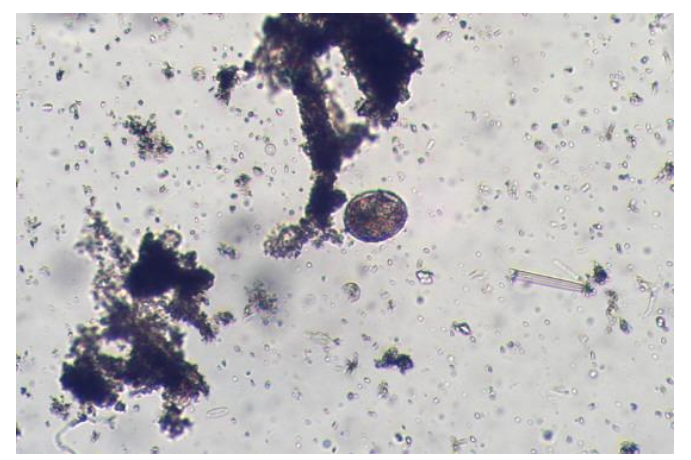

Fig.1 Protozoa Cyst in the Intestine of Tilapia zillii Collected in the Middle of Iraq

This coincides with the present results in view of the wide distribution of this fish in Central Marshes as well as other Iraqi marshes and also presence of the piscivorous birds relatively in large numbers either as migrants or resident birds including 2 pelicans, 2 cormorants, 9 herons, and the African darter (Salim et al., 2006) with wide range of distribution especially in marshy areas in the south.

The protozoa cysts (Fig. 1) are ovoid in shape, measuring about $75 \times 110 \mu \mathrm{m}$ with rather moderately thick wall. The cysts could not be identified and more future work is needed to clarify their situation. Neither blood parasites nor ectoparasites were detected in this collection.

\section{Acknowledgement}

My profound thanks to Dr. Habeeb W. K. Shubber, Dr. A. B. M. Al-Waaly, and Dr. Firas S. Al-Mayahi from the Department of Biology, College of Science, Al-Qadisiya University, Al-Diwaniya Province for their kind assistance in the field work. I would like to express my deep gratitude to Mrs. Khalida I. Hasoon from the Iraq Natural History Museum, University of Baghdad for her assistance in the lab work.

\section{References}

Abdemi-Iromini, A.O., Eze, R.N. 2011. Comparative assessment of parasite infestation of Tilapia in natural and 
cultured environments. Proceedings of the Ninth International Symposium on Tilapia in aquaculture. (Eds.) Liping, L. and Fitzsimmons, K. Shanghai Ocean University, Shanghai, China, 22-24 April 2011.

Al-Maliki, G.M., Al-Khfagi, K.K., AlShemary, A.J. 2015. Incidence of parasites in Tilapia zillii from Tigris at north of Qurna with some environmental parameters of the river. J. Basrah Res. Sci., 41(2)A: 86-92.

Aloo, P.A. 2002. A comparative study of helminth parasites from the fish Tilapia zillii and Oreochromis leucostictus in Lake Naivasha and Oloidien Bay, Kenya. J. Helminthol., 76: 95-102.

Al-Sa'adi, B.A., Mhaisen, F.T., Al-Rubae, A.R.L. 20 June 2012. The first parasitological report on the redbelly tilapia Tilapia zillii (Gervais, 1848) in Iraq. In: Proceedings of the Scientific Session "The Tilapia fish and its effect on Iraqi environment" of the Iraq Natural History Research Center and Museum, Baghdad.

Barson, M. 2004. The occurrence of Contracaecum sp. larvae(Nematoda: Anisakidae) in the catfish Clarias gariepinus (Burchell) from Lake Chivero, Zimbabwe. Onderstepoort $J$. Vet. Res., 71: 35-39.

Bichi, A.H., Ibrahim, A.A. 2009. A survey of ecto and intestinal parasites of Tilapia zillii (Gervias) in Tiga Lake, Kano, Northern Nigeria. Bajopas, 2(1): 79-82.

Eccles, D.H. 1992. FAO species identification sheets for fishery purposes: field guide to the freshwater fishes of Tanzania. Food and Agriculture Organization of the United Nations (FAO), Rome, Italy.

Mhaisen, F.T., Al- Rubaie, A.R.L., Al-Sa'adi, B.A.H. 2015. Monogenean Parasites of Fishes from the Euphrates River at AlMusaib City, Mid Iraq, Am. J. Biolo. Life Sci., 3(2): 50-57.

Riede, K. 2004. Global register of migratory species - from global to regional scales. Final Report of the R\&D-Project 80805 081. Federal Agency for Nature Conservation, Bonn, Germany.

Saleh, K.I. 2007. First recorded of Tilapia zilli (Gervais, 1848), in natural water of Iraq (Tigris River). The First Scientific Conference of Agricultures College, Universilty of Basra, 26-27.

Salim, M.A., Porter, R.F., Christensen, S., Schiermacker-Hansen, P., Al-Jbour, S. 2006. Field guide to the birds of Iraq. Amman: Nature Iraq \& BirdLife International. (In Arabic).

Teugels, G.G., Thys van den Audenaerde, D.F.E. 1991. Tilapia. pp.482-508 in J. Daget, J.-P. Gosse, G.G. Teugels, and D.F.E. Thys van den Audenaerde (Eds.). Check-list of the freshwater fishes of Africa (CLOFFA). ISNB, Brussels; MRAC, Tervuren; and ORSTOM, Paris.

Whitfield, A.K., Heeg, J. 1977. On the life cycles of the cestode Ptychobothrium belones and nematodes of the genus Contracaecum from Lake St. Lucia, Zululand. South African J. Sc., 73: 121122.

\section{How to cite this article:}

Mohammad K. Mohammad. 2016. The Parasitic Fauna of the Exotic Fish Tilapia zillii in the Middle and South of Iraq. Int.J.Curr.Microbiol.App.Sci. 5(3): 93-96. doi: http://dx.doi.org/10.20546/ijcmas.2016.503.013 